Historic, Archive Document

Do not assume content reflects current scientific knowledge, policies, or practices. 



\section{Hydrangea Arborescens Sterilis}

\section{"HILLS OF SNOW"}

This Hydrangea is one of the most satisfactory plants for the Retail Nurseryman to to handle for the following reasons:

I. It is easily grown. It is more likely to live under the neglect of the careless customer than any other shrub. It is in no sense a delicate plant.

II. It is hardy in all parts of the country and so exceedingly florifercus that customers are not only always satisfied but usually enthusiastic over it.

The plant shown on the colored plate is five years old. Two years ago I used all the wood from this plant for propagating purposes, cutting the entire top down to the ground. The photograph from which the colored plate was made, was taken last July and shows two seasons' growth of the plant.

The habit of this plant in the nursery row and in its matured state is somewhat at a variance. The bloom forms at the terminals of the new growth, which growth in the established plant matures in June and July, but in the nursery row continues to form throughout the season, the new shoots producing flowers whenever they reach their terminals. This fact has lead some to describe this Hydrangea as an everbloomer, but no one familiar with the natural habit of the matured plant will make such a claim.

For the Fall, 1908, and each season thereafter I will have a large supply of this Hydrangea, GROWN ESPECIALLY FOR THE NURSERY-MAN'S RETAIL TRADE, which gives my plants a distinct character of their own, being strong, vigorous, shapely plants, such as familiarity and long experience with the peculiar habit of this plant alone can produce.

This stock must not be confounded with the taller but light single-stemmed plants usually grown, or the stock usually handled by florists. My plants are two-year, will mostly have three to five stems and will generally run two to two and one-half feet in heighht.

The price of my SPECIALLY GROWN two-year plants for Fall, 1908, and Spring, 1909, will be 33 cents each. For the Spring, 1908, I can supply one-year plants, run ${ }^{2}$ ning from ten to twelve inches, at 25 cents.

If you will agree to buy your plants of me I will supply FREE one colored plate for each plate book you may have in actual use, and will supply circulars with name and address printed thereon as follows:

\footnotetext{
No. I. 'Two Page-\$3.00 per I000, or 500 for $\$ 2.00$

No. 2. Two Page- 4.50 per I000, or 500 for $\$ 2.50$

No. 3. Four Page-\$5.50 per I000, or 500 for $\$ 3.00$
}

Circulars without name and address in small lots as follows:

TWO PAGE, 50 cents per IDO

FOUR PAGE, 75 cents per IOO

Awaiting your response, I am yours truly, 
